\title{
RESEARCH PAPER \\ EVALUATION OF LIBRARY RESOURCES: A STUDY OF SIR ARKU KORSAH LAW LIBRARY, KWAME NKRUMAH UNIVERSITY OF SCIENCE AND TECHNOLOGY, KUMASI, GHANA
}

\author{
Akua Asantewaa Aforo \\ Faculty of Law Library, KNUST, Kumasi \\ E-mail: akuaaforo09@yahoo.com/akuaaforo09.lib@knust.edu.gh
}

\begin{abstract}
Two years after the establishment of the Sir Arku Korsah Law Library in the Faculty of Law, KNUST-Kumasi, Ghana, there is the need to evaluate services provided to its patrons in order to continually improve upon them. The study was therefore aimed at evaluating the library's resources and services to students of the Faculty of Law, KNUST, and the Ghana School of Law, Kumasi Campus. Designed questionnaire with self-explanatory closed and open-ended questions on the library use and the library's computer facility among others were administered to 112 students (obtained by convenience sampling) in a cross-sectional quantitative survey at the library, KNUST. Questionnaire responses were analyzed and plotted using SigmaPlot 11. Seventy four students (66.07\%) indicated they visit the library either daily or two to three times a week, nineteen students $(16.96 \%)$ visit the library between once a week and once a month, and nineteen (16.96 \%) visit during examination period. Facilities mostly used are reference books (36.6\%). Sixty four (57.1\%) students use the library for reference and reading only, while thirty two (28.5\%) come in to use the computer facility and sixteen (14.4\%) to make photocopy. Fiftyone percent accessed the computer facility once or twice a week. Ninety nine students (88\%) endorse the presence of the ICT section in the Library and describe it as a vital service for research work. Seventy one (63\%) indicate that the library is not friendly to the physically challenged. In conclusion, the reference and the ICT sections need to be expanded and services improved.
\end{abstract}

Keywords: Electronic Information, Reference books, Reading and Research, Law Library

\section{INTRODUCTION}

A library is a place where literary and artistic materials, such as books, reports, periodicals, newspapers, pamphlets, prints, records, tapes, online and offline data bases (which are systematically arranged), are kept for reading, reference, lending, or conservation/preservation. Libraries are one of the most important facili- ties in the learning and research process (Baughman, 2007) therefore the right resources and services should be made available to its users. Students, lecturers, and researchers in academic institutions rely on libraries to provide the information they need in support of teaching, learning, research and knowledge dissemination, which is a fundamental reason 
for a library's existence (Aina, 2004; Jubb and Green, 2007; Agyen-Gyasi et al., 2010). Oyesiku and Oduwole (2004) assert that in academic communities, libraries are indispensable. Libraries of all sizes and types are embracing digital collections, although most of them will continue to offer both print and digital collections for many years to come (Tenopir, 2003).

Every library exists to serve the needs of its community of users. The evaluation of a library is based on how well it serves these needs. Meeting user needs necessitates a study of those needs (Kannappanavar and Swamy, 2010). Progress in science and technology means that libraries must provide variety of services to their users. To achieve this, it is necessary to have continuous feedback from users. The effectiveness and efficiency of services provided in academic libraries are mainly determined by library users. Behling and Cudd (1967) assert that the library user is regarded as the most logical source to determine whether the library is playing its role satisfactorily or not. Perera (2005) submits that satisfying user needs is essential to the management of libraries.

Legal education is essentially a multidiscipline and multipurpose education which can develop the human resources and idealism needed to strengthen the legal system. Since law plays a significant role in the process of socioeconomic progress of the country, training of lawyers should receive a high level of attention (Law School Companion, 2011).

The Faculty of Law Library building at the Kwame Nkrumah University of Science and Technology (KNUST), Kumasi, Ghana, was purposefully erected and completed by the University with funds provided by the Ghana Educational Trust Fund (GETFund) as a requirement for the establishment of a Law Faculty in KNUST. The building was commissioned on Tuesday $19^{\text {th }}$ September 2006. The Library was named after the first black Chief Justice of Ghana (then Gold Coast) in 1956, Sir Kobina
Arku Korsah (1894-1967) for his immense contribution to Legal Education in Ghana. The establishment of the Law Library was to give prospective lawyers access to legal information services that meet the legal research and information needs of Law Library users to enhance their legal education in Ghana.

The Sir Arku Korsah Law Library, which started as a section in the KNUST Main University Library in 2003, was moved to the Faculty of Law with its full set of staff in August 2009 , to stress the importance of library and information services for law research, teaching, learning and knowledge dissemination. The Law Library is an integral part of the Faculty of Law, KNUST, Kumasi and it is financed by the Faculty. The library is considered a laboratory of a scientific institute, where the apparatus for the law students are the classic law books, case law reports and journals that are available in full sets (HNLU, 2010). The students would perform legal research like experiments to augment their studies by using the law materials.

The materials available have an impact on the teaching and learning process as both lecturers and students obtain vast information for teaching and learning from the Library.

There is no doubt that a library is the 'heart' of any academic institution of higher learning. It plays a significant role in the pursuit of academic excellence, especially in law institutions where the importance of a library increases many times as the entire teaching-learning is mostly library dependent.

It is a policy of the library to primarily serve the law students and staff and assist other legal practitioners as time permits. After two years of operation, there is the need to evaluate infrastructure, book stock, financial and human resources as well as the organization and the use of facilities/resources, services and their impact on the teaching-learning process in the faculty. 
This evaluation would be of importance to the KNUST as a whole since the library plays an important role in research at the Faculty of Law in particular and the university in general.

It is in this light, that this study has been conducted on the overview and evaluation of the library's resources to help enhance or improve upon services provided by the library to satisfy all its category of users. The study also identifies the types of library and information services required by users, elicit opinions about services offered by the library, challenges faced by users, and the adequacy of information resources and their use.

\section{METHODOLOGY}

The study was a cross- sectional quantitative survey. At the time of the study, 150 students from the Faculty of Law, KNUST, Kumasi and the Ghana School of Law, Kumasi Campus, were in the Sir Arku Korsah Law Library which has a seating capacity of 172 (the second largest library in KNUST). The library was then $87.2 \%$ full. By convenience sampling 112 students agreed to be respondents for the study. Designed questionnaire with self-explanatory close and open-ended questions on the subject (library use and the library's computer facility among others) including demographics were administered and retrieved by the researcher within the same day. However, clarification was given to respondents who needed some assistance. Questionnaire responses were analyzed using the SigmaPlot statistical package version 11 .

\section{RESULTS}

Of the 112 copies of the questionnaire properly filled by the students, $107(96 \%)$ were from the Faculty of Law, KNUST, Kumasi, and 5 (4\%) were from the Ghana School of Law, Kumasi Campus. Sixty nine (62\%) were male and forty three $(38 \%)$ female. Forty eight $(42.9 \%)$ of the students were aged 25 years and below while nine $(8.0 \%)$ were between 46 and 55 years. Bachelor of Laws (LL.B.) students in the fourth year were in the majority $(36 \%)$ as shown in
Fig. 1. Sixty four $(57.1 \%)$ were full-time students.

\section{Library use}

Seventy four students $(66.1 \%)$ indicated they visit the library either daily or two to three times a week, and nineteen $(17.0 \%)$ visit during examination period (Fig. 2).

Of all the facilities in the library, the most widely used by students are reference books; $50.9 \%$, and reports; $29.5 \%$ (Figure 3). Sixty four students $(57.1 \%)$ use the library for reference and reading only while thirty two $(28.5 \%)$ come in to use the computer facility and sixteen $(14.4 \%)$ to make photocopy. Seventy students $(62.5 \%)$ think that the stock of materials is good while forty-two students $(37.5 \%)$ think there is more room for improvement.

\section{Library computer facility}

Although thirty two students $(28.5 \%)$ come in to use the computers for Microsoft office applications (Word, Excel, and PowerPoint) and Internet applications (email and open learning courses), seventeen (53.1\%) of these (32) individuals only use the internet to seek information to support their course of study or for independent learning. As to the frequency of the use of the computer facility in the library, $51 \%$ access it once or twice a week; $31 \%$ once a while; $13 \%$ fortnightly and 5\% once a month. To find out if the library is the only place of computer facility accessibility, twenty four students (21.4\%) affirm while eighty eight $(78.6 \%)$ have access elsewhere. One hundred and four students $(92.9 \%)$ consider themselves as intermediate to very experienced computer users (Figure 4). Out of the total number sampled (112), ninety four (84\%) are interested in being given additional training on the use of computer to access information.

Ninety nine students $(88 \%)$ are of the opinion that computer facilities in the library are so important that without these, studies would be difficult and $91 \%$ describe them (computer facilities) as a vital service. Almost all the stu- 


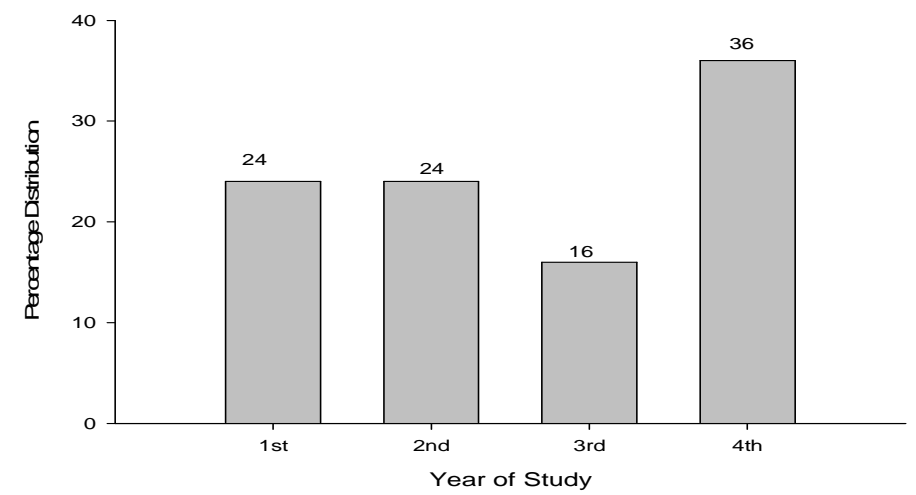

Fig. 1: Year of study of the students interviewed

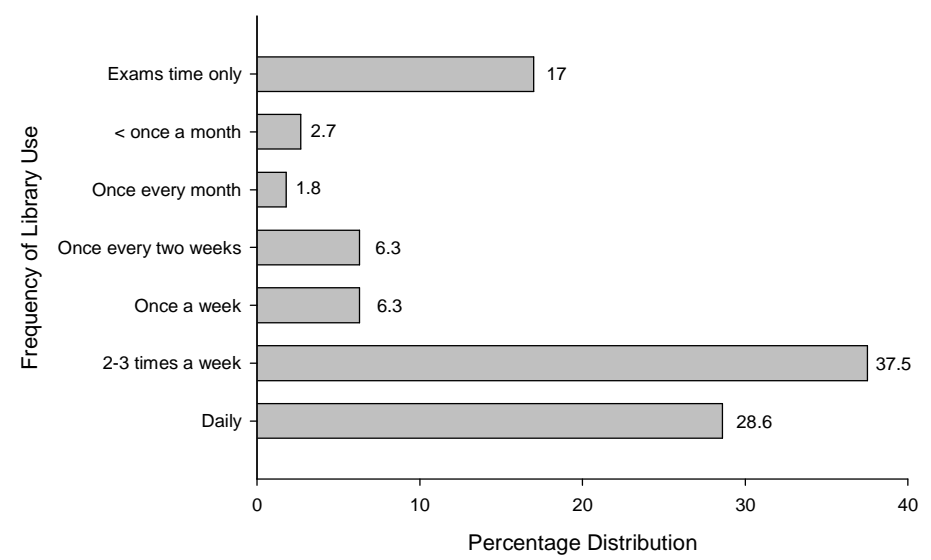

Fig. 2: The frequency of library use

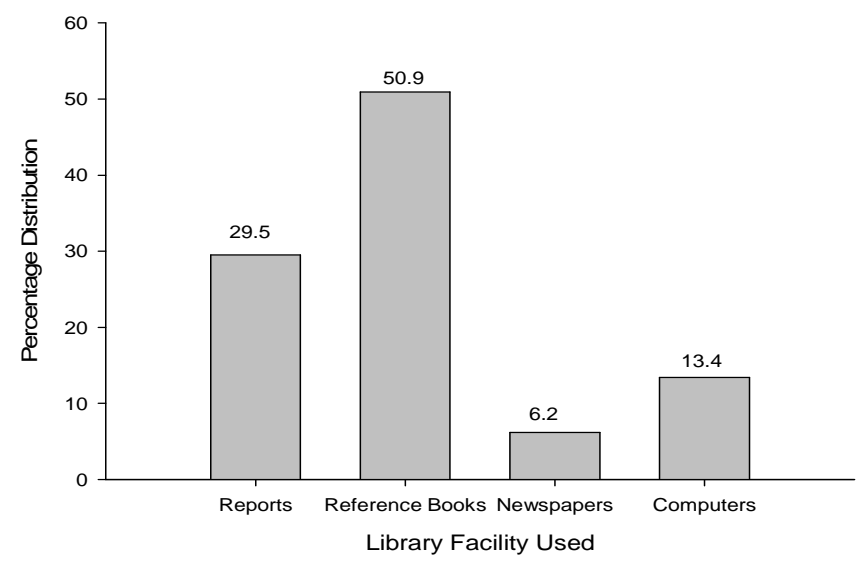

Fig. 3: Library facilities students use most

Journal of Science and Technology 다 KNUST December 2012 
dents assert that lack of computer facilities from the library would affect them, especially in their research work (Fig. 5).

\section{Infrastructural convenience}

Basic facilities available and the services the library provides are Information Services with Online Public Access Catalogue (OPAC); Photocopying Services; Electronic Information and Printing Services; Reading Area; Discussion room; Study Carrels for staff and legal practitioners. All students indicate that to the normal individual, the infrastructure (the organization, structure, setup, arrangement, etc) of the reference, reading, ICT and photocopying areas are very good. Seventy one students $(63 \%)$ indicate that the reading area in the library is not friendly to the physically challenged.

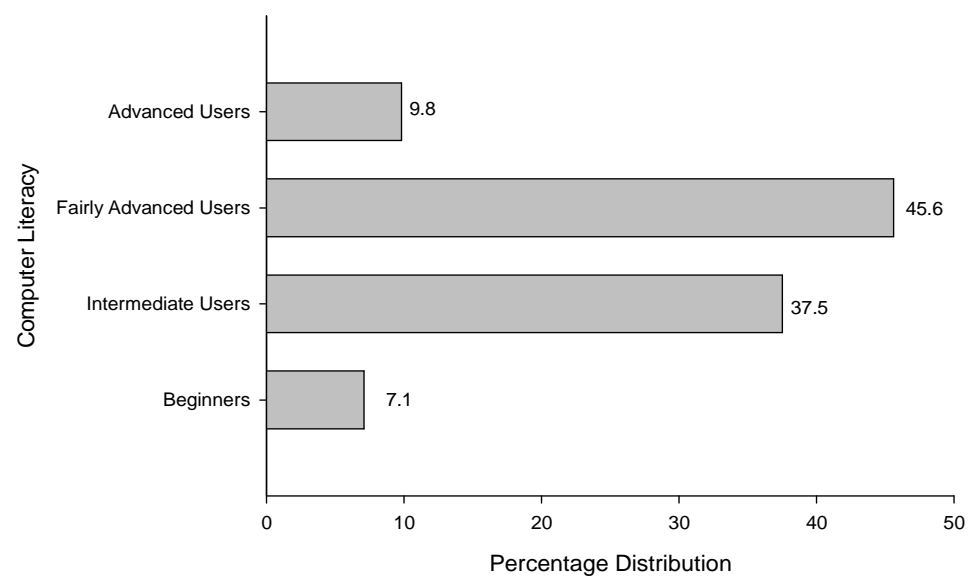

Fig. 4: Computer literacy among the students

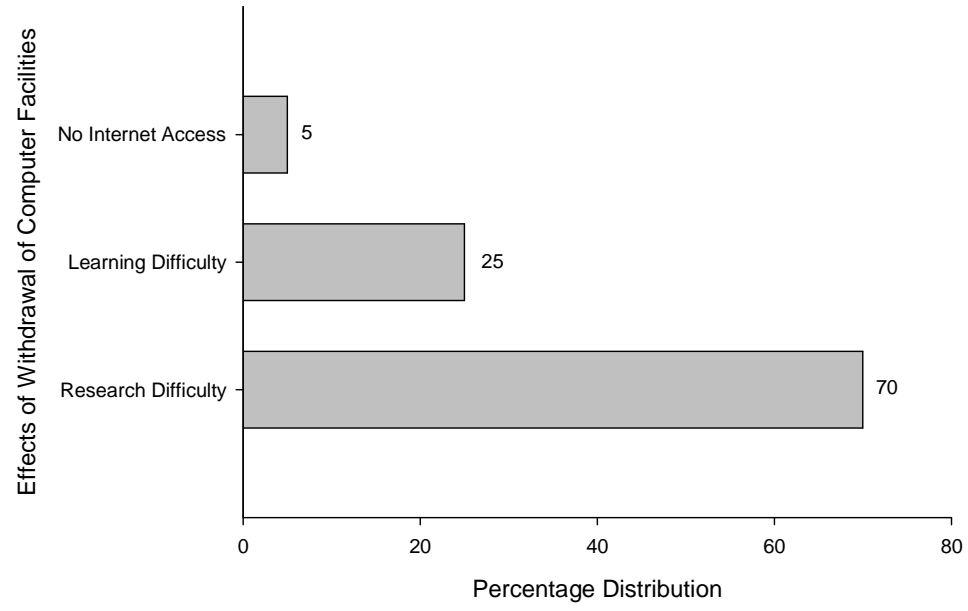

Fig. 5: Suggested effects of the withdrawal of the computer facilities from the library 


\section{DISCUSSION}

Most library users visit the library for reference materials (Ugah, 2007), and this is what prevails in the Sir Arku Korsah Law Library. Most students come to the library for law reports and reference books. The total number of collections in the library is 8,816 excluding Journals of different titles; Project Work; and Newspapers.

The library has a lot of foreign reports. For example, the All England Law Reports [All ER] from 1929 to 2007; Halsbury's Laws of England; Kings Bench Division; Queens Bench Division; Chancery Division; Common Pleas Cases; Dominion Law Reports and The Digest. However, the Ghana Law Reports [GLR] are from 1959 to $1993 / 1994$; the Supreme Court of Ghana Law Reports [SCGLR] are from $1996 / 1997$ to $2007 / 2008$. Most of the Ghana collections, especially the reports need to be updated since the reports are the only access points for students. They would always find the cases there to augment teaching and learning in the faculty. The text (reference) books that are relevant to the programmes run in the Faculty are not adequate, in terms of titles and number of copies in the library, so most of them are kept separately for short loans within the library. The only print journals students find useful are the KNUST Law Journal and University of Ghana Law Journal, the rest do not satisfy their needs as compared to those recommended by the Faculty.

Electronic resources would be very useful in the reference area of the library (Tenopir, 2003). Online and offline databases for books, annuals, and journals on law are of necessity. Currently, some of the electronic resources relevant, available and accessible to the users of the library are: Jstor - www.jstor.org; Mary Ann Liebert, Inc., Publisherswww.liebertonline.com; Project Muse - http:// muse.jhu.edu; University of Chicago Press www.journals.uchago.edu; Willey Online Library/Blackwell-http://onlinelibrary.willey.com and International Criminal Tribunal for
Rwanda (ICTR) jurisprudence www.ictrcaselaw.org. The reference area has an Online Public Access Catalogue (OPAC) that students use to search for printed materials as well, by title or author, with adequate, qualified library staff to assist them. But students hardly make good use of it since they know easily where to find the needed materials. There is therefore the need for user education for all new students in the faculty.

Most academic libraries organize orientation for new users. The Hadyatullah National Law University (HNLU) Library in New Raipur, Chhattisgarh, India conducts library orientation programme for the fresh students to acquaint them with the library system, services and resources so that they may exploit the available resources for their maximum benefit (HNLU, 2010). Similarly, the Institute of Advanced Legal Studies (IALS) Library, London, and the KNUST Library System run library orientations for their new students, therefore it is important that such an activity is undertaken for all fresh students of law in the faculty as well.

The majority of students visit the library either daily or two to three times a week but some also visit only during examination period because that is the period the library extends its opening hours. Probably, the part-time students amongst them do not get time to visit but only when the library opens longer. The KNUST Main Library opens from 9:00 am to 11:00 pm on Monday to Friday and 9:00 am to 2:00 pm on Saturday, but all the libraries in the various colleges open from 9:00 am to 5:00 pm on Monday to Friday with extension to 9:00 pm after mid-semester. The Sir Arku Korsah Law Library is no exception, so students make good use of the library during the stipulated opening hours and proceed to the Main Library when the need arises.

Even though the majority of students consider themselves as intermediate to very advanced computer users, only about a quarter of the students come in to use the ICT section of the li- 
brary on regular days (except for course registration which is at the beginning of the semester). To some students, the library is the only place where they get access to free computer facilities and internet services. Work stations with internet connectivity and printing facilities are accessible to all users in the ICT section for searching the library's collections, reading CDROMs, and accessing the Internet. The Library does not have any course related software yet for users but students have access to online databases for research. The library staff is available to assist students, especially those who are non-computer literates, at the ICT section.

Students' suggestions imply that the ICT section of the library could be improved. That the number of computers must be increased; students should not be timed on the use of computer; there should be the provision of internet Wi-Fi (wireless) facility in the library so that even when the library is closed, users can sit around the library for internet access.

In order to utilize the growing range of electronic resources, students must acquire and practice the skills necessary to exploit them (Obuh, 2009). Students know the importance of the ICT section of the library and have expressed interest in being given training on the use of computers to access information. As Dutton (1990) suggests, the skills required to maximize the potential of electronic resources are much greater than those required for searching printed sources. The library has made it a policy to give students the needed training on the use of ICT for legal research, provided they would make themselves available. "For students using a variety of on-line databases, it is as though they were parking lot attendants, where every vehicle is not only a different make and model but has a different configuration" (Blandy and Libutti, 1995).

It is now a norm that all public places should be friendly to the physically challenged (Ramachandran, 2008; Wisconsin Code, 2011).
However, the reading area of the Library is located in the balcony and accessed only by staircases which are not disability friendly. A reading area for such persons should be created on the ground floor and subsequently, elevators considered.

\section{CONCLUSION AND RECOMMENDA- TIONS}

The nature of information services provided by the Sir Arku Korsah Law Library, KNUST, Kumasi is according to the range of interest of the user community. With the emergence of the computer and revolutionary changes in communication technology, it has become necessary for this law library to provide a variety of technology based information services to users with a wide range of interests. Though the library is at its initial stage of development, modern technologies required are satisfying the information needs of its users but the sky is the limit. The library needs to be stocked with current Ghanaian hard and soft copies of materials. Databases of students' project work, journal articles, etc. must be made available to users. Online and offline data bases for law reference materials should be urgently accessible to students and the number of computers should be increased.

\section{REFERENCES}

Agyen-Gyasi, K., Lamptey, R. and Frempong, A. (2010). Academic librarians' role in maximizing library use in Ghana. University library, Kwame Nkrumah University of Science and Technology, Ghana. Available at: http://dspace.knust.edu.gh:8080/jspui/ handle/123456789/561. Accessed on June 20, 2011.

Aina, L. O. (2004). Library and information science text for Africa. Ibadan: Third World Information Services.

Baughman, S. (2007), Teaching, learning, and research: Libraries and their role in the academic institution. Available at http:// ww.arl.org/rtl/roles/tlr.shtml. Accessed on June 24, 2011. 
68

Behling, O. and Cudd, K. (1967). A library looks at itself. College and Research Libraries, 26(8), 416-422.

Blandy, S. G. and Libutti, P. (1995). As the cursor blinks: Electronic scholarship and undergraduates in the library. Library Trends 44 (2): 279-305.

Dutton, B. G. (1990). An introduction to enduser searching. In: Bysouth, P. T. (ed) Enduser searching: the effective gateway to published information. London: Aslib,1-18.

Hidayatullah National Law University (2010). Library (hnlu.ac.in (C) 2010). Available at: http://www.hnlu.ac.in/home/index.php? opion=com_content\&task=view\&id=29\&Ite mid=59. Accessed on: July 16, 2011.

Jubb, M. and Green, R. (2007). Researchers' use of academic libraries and their services. Available at: http://www.rin.ac.uk/system/ files/.../Researchers-libraries-servicesreport.pdf. Accessed on: June 29, 2011.

Kannappanavar, B. U. and Swamy C. H. M. (2010). User perception of library and information services in agricultural science universities in South India: An evaluative study. Library Philosophy and Practice 2010 (ejournal) (April) University of Nebraska Lincoln. http://unllib.unl.edu/LPP/ kannappanavar-swamy.htm. Accessed on June 24, 2011)

Law School Companion (2011). Importance of legal education (Copyright (C) 2011,). Available at: http://ww.lawschoolcompanion.com/ law-culture/importance-of-legaleducation.html. Accessed on July 16, 2011.

Obuh, A. O. (2009). Use of electronic resources by postgraduate students of the Department of Library and Information Science of Delta State University, Abraka, Nigeria, Library Philosophy and Practice 2009 (November)
http://unllib.unl.edu/LPP/obuh-alex.htm Accessed on June 24, 2011

Oyesiku, F. A. and Oduwole, A. A. (2004). Use of an academic library: A survey on the Olabisi Onabanjo University Libraries. Lagos Journal of Library and Information Science, 2(2), 96-101.

Perera, P. A. S. H. (2005). A study on the pattern of usage of library facilities at the Medical Library, University of Peradeniya. Journal of the University Librarians Association of Sri Lanka, 9: 41-61. Retrieved on June 29, 2011 from http://www.sljol.info/index.php/ JULA/article/viewFile/312/355

Ramachandran, M. (2008). Accessibility of public places including transport to physically challenged persons. Available at http:// www.urbanindia.nic.in/programme/ut/ K_1401142008_UT.pdf. Accessed on July $16,2011$.

Tenopir, C. (2003). Use and users of electronic library resources: An overview and analysis of recent research studies: Council on $\mathrm{Li}^{-}$ brary and Information Resources Washington, D.C.

Ugah, A. D. (2007). Evaluating the use of university libraries in Nigeria: A case study of Michael Okpara University of Agriculture, Umudike. Library Philosophy and Practice, 2007.Retrieved June 29, 2011 from http:// www.webpages.uidaho.edu/ mbolin/ ugah2.htm

Wisconsin Code, (2011). Department of commerce--regulation of industry, buildings and safety. Physically disabled persons; place of employment and public building requirements (Justia US law.com), 101.13. Available at: http://law.justia.com/codes/ wisconsin/2011/101/101.13.html. Accessed on July 16, 2011 